\title{
Steel sheets partnered with quenchable sheet in hot stamping of tailor-welded blanks and its application to separation prevention of fractured components
}

\author{
Ken-ichiro Mori $^{1} \cdot$ Yasutaka Suzuki $^{2} \cdot$ Daisuke Yokoo $^{1} \cdot$ Michiya Nishikata $^{1} \cdot$ Yohei Abe $^{1}$
}

Received: 21 May 2020 / Accepted: 14 September 2020 / Published online: 3 October 2020

(C) The Author(s) 2020

\begin{abstract}
The phase transformation and mechanical properties of non-quenchable steels partnered with the quenchable boron steel in hot stamping of tailor-welded blanks were evaluated to produce tailored components with partially balanced strength and ductility. The effect of the forming start temperature after natural air cooling on the phase transformation and mechanical properties for 270 MPa mild steel, non-quenchable steel, $440 \mathrm{MPa}$ high strength steel, and 22MnB5 steel sheets was examined, and the $270 \mathrm{MPa}$ and non-quenchable sheets had enough ductility after hot stamping. Tailored components having a hardness of about $500 \mathrm{HV} 1$ in the high strength zone and a total elongation of about $30 \%$ in the high ductility zone were hot-stamped from a tailor-welded blank composed of $22 \mathrm{MnB} 5$ and $270 \mathrm{MPa}$ sheets. It was found that the $270 \mathrm{MPa}$ mild steel sheet is sufficient as a partner sheet of tailorwelded blanks. In addition, the safety of hot-stamped components was heightened by welding a 22MnB5 main blank with a 270 MPa steel patch. Even if the main blank is fractured by a collision, the hot-stamped component is not separated by the $270 \mathrm{MPa}$ patch having high ductility.
\end{abstract}

Keywords Hot stamping · Tailor-welded blank · Partner steel sheet · Ductility $\cdot$ Component separation

\section{Introduction}

To heighten the crash safety of automobiles without weight increase, ultra-high strength steel components of body-inwhite have been increasingly produced by hot stamping. In hot stamping, heated quenchable steel sheets are formed and then are quenched by being held with cold dies at the bottom dead centre of a press [1]. The high strength of the components is gained by means of microstructure control through both austenite and martensite transformations, and the heat treatments are included in stamping operations. Die quenching leads to another advantage of small springback of hot-stamped components due to plastic deformation induced by volume expansion of the martensitic transformation during holding at the bottom

Ken-ichiro Mori

mori@plast.me.tut.ac.jp

1 Department of Mechanical Engineering, Toyohashi University of Technology, Toyohashi, Aichi 441-8580, Japan

2 TOA Industries Co., Ltd., 26-1 Nishishin-machi, Oota 373-0847, Japan dead centre [2]. Most of steel sheets used for hot stamping are manganese-boron steel 22MnB5, and the tensile strength of the formed components is about $1.5 \mathrm{GPa}$. The superiority of the high strength for hot stamping is being lowered by the development of new 1.5 GPa ultra-high strength steel sheets used for cold stamping [3], because cold stamping has the advantages of high productivity, conventional and cheaper equipment, no oxidation prevention treatment, etc. It is desirable to generate additional advantages of hot stamping.

Although the strength of steels generally decreases with increasing ductility, the crash safety of automobile components such as A and B-pillars is improved by partially increasing the ductility because of the rise in energy absorption [4]. Hot stamping is suitable for producing tailored components with partially balanced strength and ductility. Merklein et al. [5] gave a detailed review of tailored hot stamping processes, and Mori el al. [6] classified these processes into heat treatments and tailored blanks. Since both austenite and martensite transformations are required to attain high strength of components, the formed components are not hardened by preventing one of the two transformations, and the ductility becomes high. In tailoring using the heat treatments, the austenite or martensite transformation is partially prevented in components. By partially heating sheets above 
and below the austenitisation temperature, the stamped components have both high strength and high ductility zones. In $22 \mathrm{MnB} 5$ quenchable steel sheets commonly employed for hot stamping, the austenitisation temperature is about $800{ }^{\circ} \mathrm{C}$. Wilsius et al. [7] partially covered steel sheets with heat shields in a heating furnace to prevent the austenite transformation. Landgrebe et al. [8] partially heated sheets by sandwiching between heating plates having a temperature distribution. Mori et al. [9] partially heated sheets with bypass resistance heating in which zones in contact with copper bypasses having a low resistance and large cross-sectional area were not heated due to the passage of most of current though the bypasses. MaikranzValentin et al. [10] pre-heated steel sheets below the austenitisation temperature, and then partially inductive-heated these sheets above the austenitisation temperature for die quenching.

The martensite transformation is partially prevented by decreasing the cooling rate of the high ductility zone in the heated sheet during die quenching. Tailored tempering is the most typical process of the partial martensitisation. Dies used for hot stamping are generally water-cooled to attain a high cooling rate; conversely, dies are partially heated in order to drop the cooling rate for tailored tempering, and both heating and cooling regions exist in the die. For the 22MnB5 boron steel sheets, the martensite transformation does not occur below 30 ${ }^{\circ} \mathrm{C} / \mathrm{s}$ in cooling rate, and softer ferrite and bainite appear. Fernandez et al. [11] exhibited strategies of the tailored tempering. Tang et al. [12] predicted microstructure of hot-stamped components produced by tailored tempering for various heating temperatures of dies. Bardelcik et al. [13] examined the mechanical properties, microstructure, and damage of tailored components. Omer et al. [14] examined the crush behaviour of a component produced by tailored tempering from an experiment and FEM simulation. Nakagawa et al. [15] developed tailored tempering processes without heating of dies.
Tailored blanks having optimal differences in thickness and material are increasingly applied for automobile components [16]. The flexibilities in product design, formability, structural stiffness, crash safety, etc., are improved by means of tailor-welded blanks. The tailored blanks are mainly produced by laser butt welding of several sheets. Min et al. [17] evaluated the weldability and formability of tailor-welded blanks for automobile clutch parts. Kinsey et al. [18] applied force to welds of a tailor-welded blank during stamping to increase the formability. Chan et al. [19] evaluated the formability of tailor-welded blanks having different thicknesses. Padmanabhan et al. [20] optimised the blankholder force in square cup drawing of a tailor-welded blank to improve the drawability.

The tailor-welded blanks are mostly employed for cold stamping, and the application to hot stamping processes also increases. Although the formability in cold stamping of tailor-welded blanks is greatly influenced by low ductility near the welds, its ductility is improved by heating in hot stamping. Tailored hot stamping using the tailorwelded blanks is more flexible than that using the heat treatments because of partial different thickness and no die heating, whereas the cost of the blank is higher due to laser welding. Tailored components having partially balanced strength and ductility can be hot-stamped from tailor-welded blanks consisting of quenchable and nonquenchable steel sheets. Choi et al. [21] examined the hot stretch flangeability of tailor-welded blanks composed of quenchable boron and non-quenchable $340 \mathrm{MPa}$ steel sheets. The hot formability of the quenchable steel sheet at elevated temperatures is similar to that of the nonquenchable sheets. Choi et al. [22] simulated deformation behaviour and phase transformation in hot stamping of a tailor-welded blank and in hot stamping using tailored tempering. Kang et al. [23] examined the effects of welding
Fig. 1 Phase transformation in hot stamping of tailored components having partially high strength and ductility from tailorwelded blank

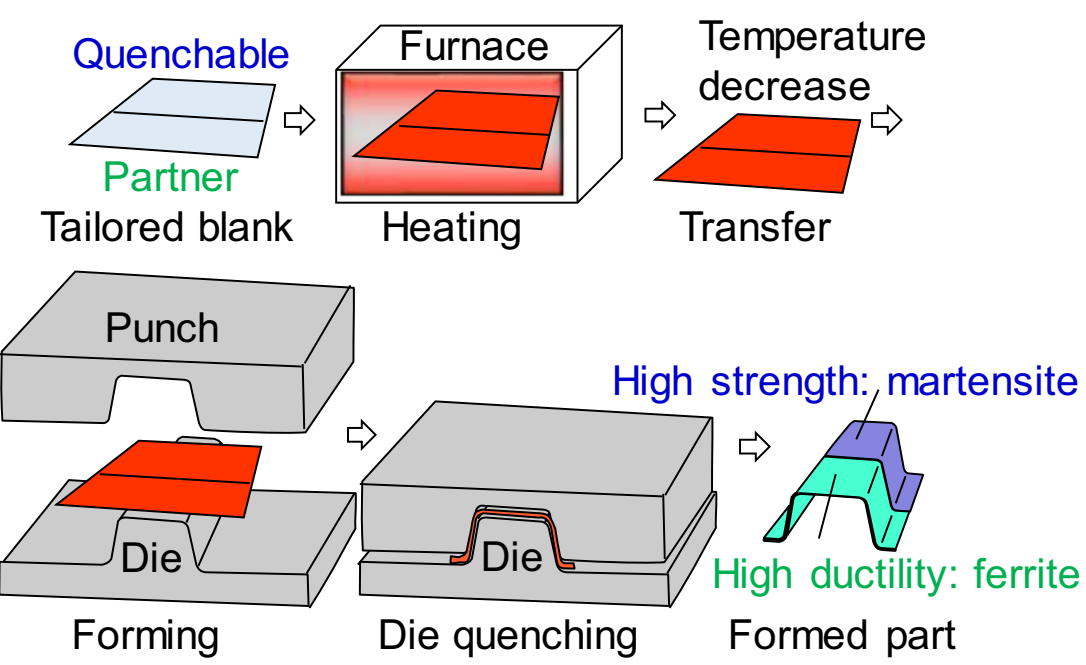


Table 1 Chemical composition of steel sheets used for experiment

\begin{tabular}{llllll}
\hline & & \multicolumn{4}{l}{ Chemical composition (wt\%) } \\
\cline { 3 - 6 } & & $\mathrm{C}$ & $\mathrm{Mn}$ & $\mathrm{B}$ & $\mathrm{Si}$ \\
\hline \multirow{2}{*}{ Partner } & Non-quenchable & 0.064 & 0.75 & 0.0003 & 0.191 \\
& $270 \mathrm{MPa}$ & 0.05 & 0.22 & - & 0.01 \\
& $440 \mathrm{MPa}$ & 0.17 & 0.68 & - & 0.01 \\
\multirow{2}{*}{ High strength } & $22 \mathrm{MnB5}$ & 0.21 & 1.22 & 0.003 & 0.26 \\
\hline
\end{tabular}

and heating conditions on the microstructure near the weld in hot stamping of a tailor-welded blank. Tang et al. [24] examined the effect of weld seam locations on deformation behaviour in hot stamping of tailor-welded blanks from the finite element simulation.

For non-quenchable steels partnered with the quenchable boron steel in hot stamping of a tailor-welded blank, it is required to have appropriate ductility and strength after the same heating, forming and die quenching operations as the boron steel. Tang et al. [25] evaluated the mechanical properties of partner steels in hot stamping of tailor-welded blanks. Kong et al. [26] developed one-step quenching and partitioning treatment of a tailor-welded blank composed of boron and TRIP steels. Ductibor ${ }^{\circledR}$ [27] is commonly employed in industry as a partner steel, whereas this steel is costly and the suppliers are limited. It is desirable in industry to investigate anti-quenchability of partner steels in hot stamping of tailor-welded blanks.

In the present paper, the applicability of the conventional steel sheets used for cold stamping as partner sheets in hot stamping of tailor-welded blanks was evaluated. The phase transformation and mechanical properties of partner steel sheets in hot stamping of tailor-welded blanks were examined. The phase transformation of the steel sheets for heating and cooling histories of hot stamping operations was measured, and the ductility and strength of the quenched sheets were evaluated. In addition, an approach for improving the safety of hot-stamped components using a $270 \mathrm{MPa}$ sheet having high ductility after die quenching is proposed.

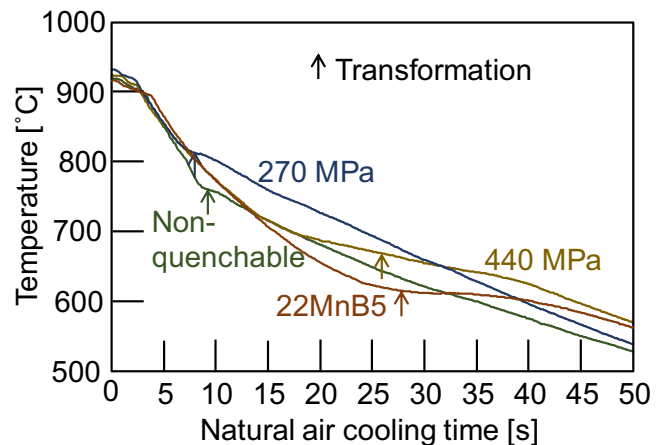

Fig. 2 Variation in temperature and phase transformation of 4 steel specimens in natural air cooling

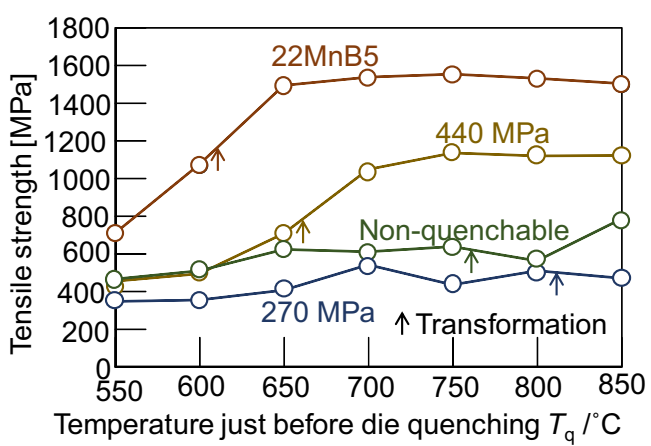

Fig. 3 Relationship between tensile strength and temperature just before die quenching for 4 sheets

\section{Phase transformation and mechanical properties of partner steel sheets without forming}

\subsection{Partially high strength and ductility in hot stamping of tailor-welded blank}

In hot stamping of tailored components having partially high strength and ductility from tailor-welded blanks, welded quenchable and partner steel sheets are heated, transferred, formed, and die-quenched under the same temperature history, as shown in Fig. 1. Both quenchable and partner steel sheets are transformed into austenite by heating. During the transfer from the furnace to the dies, the temperature of the blank decreases due to natural air cooling. When the transfer time is long, the quenchable steel sheet is transformed into ferrite during the transfer and is not hardened without the martensite transformation even for die quenching anymore. On the other hand, a long transfer time is desirable for the partner steel sheet to obtain high ductility by the ferrite transformation during the transfer. It is required that the transformation during the transfer is prevented for the quenchable steel sheet and is caused for the partner steel sheet. Since the forming start temperature is changed by the transfer time, the effect of the forming start temperature on the phase transformation, the strength, and ductility of the quenchable and partner steel sheets is examined.

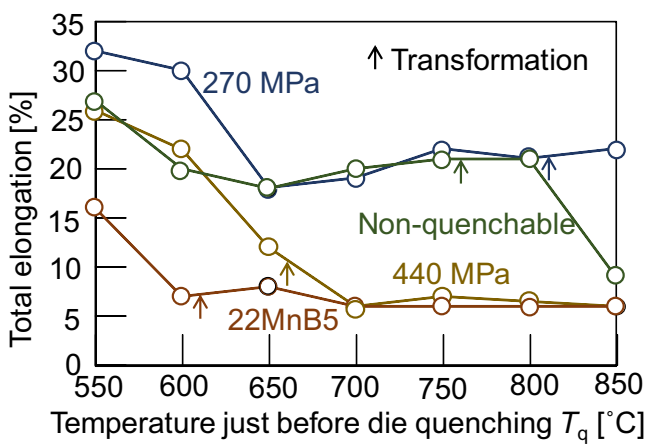

Fig. 4 Relationship between total elongation and temperature just before die quenching for 4 sheets 


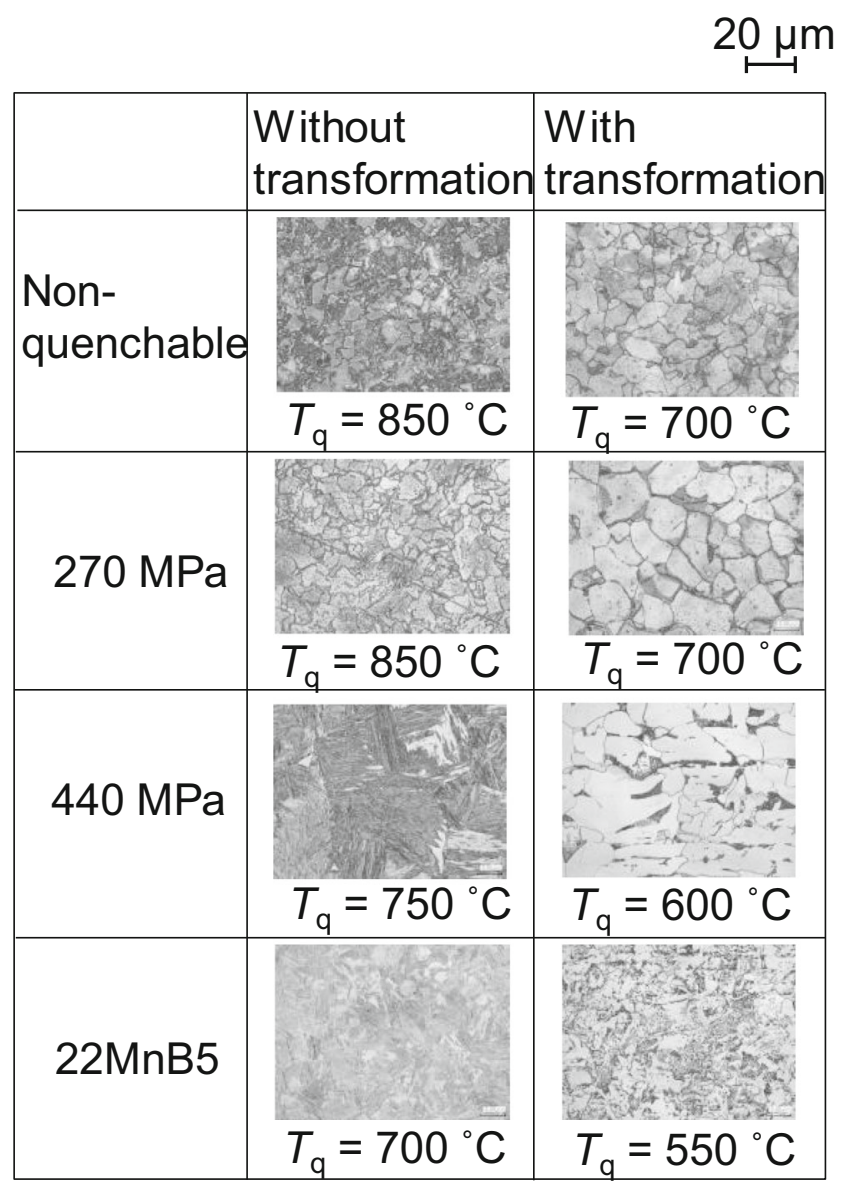

Fig. 5 Microstructures of die-quenched sheets without and with phase transformation during natural air cooling

\subsection{Experimental procedure and natural air cooling}

The quenchable steel sheet of the tailor-welded blank was an Al-Si coated 22MnB5 steel generally used for hot stamping, and the partner steel sheets were a non-quenchable steel, 270 MPa mild steel, and $440 \mathrm{MPa}$ high strength steel, where the non-quenchable steel sheet is commonly employed for as a partner sheet of the tailor-welded blank and $270 \mathrm{MPa}$ and 440 MPa steel sheets are conventional steel sheets used for cold stamping. The thickness of all the sheets was $1.6 \mathrm{~mm}$. The chemical composition of the steel sheets used for the experiment is given in Table 1 .
A tensile specimen with a width of $25 \mathrm{~mm}$ and a gauge length of $50 \mathrm{~mm}$ was heated to $910^{\circ} \mathrm{C}$ for $330 \mathrm{~s}$ in an electric furnace to be transformed into austenite. The heated specimen was naturally air-cooled after taking out of the furnace. The temperature of the specimen was measured by a thermocouple at the surface of the middle of the gauge section.

The phase transformation of the 4 steel sheets under natural air cooling was measured. In hot stamping, the temperature during the transfer from a furnace to dies is decreased by natural air cooling, and the cooling rate during this period is low. The variation in temperature and the phase transformation of the 4 steel specimens in natural air cooling are shown in Fig. 2. When the slop of the temperature curve becomes small, the latent heat appears, and the phase transformation occurs. Once the ferrite transformation appears for the $22 \mathrm{MnB} 5$ sheet, the martensite transformation does not occur even for rapid cooling, and thus, high strength is not attained. The time up to the transformation of the $22 \mathrm{MnB} 5$ sheet is a limit of natural air cooling for hot stamping. On the other hand, for the partner sheets, the transformation during natural air cooling leads to the high ductility, and the $270 \mathrm{MPa}$ and non-quenchable steel are early transformed. The ferrite transformation of the $22 \mathrm{MnB} 5$ sheet is prevented by this early transformation.

\subsection{Effect of forming start temperature}

In hot stamping, heated steel sheets are formed after natural air cooling during transfer to dies, and the forming start temperature has a great effect on the phase transformation and mechanical properties. This effect was evaluated from quenching with cold flat dies without forming. The tensile specimens were naturally air-cooled after taking out of the furnace, as shown in Fig. 2, and were quenched from a temperature between 850 and $550{ }^{\circ} \mathrm{C}$.

The relationship between the tensile strength and the temperature just before die quenching, $T_{q}$, for the 4 sheets was shown in Fig. 3, where this temperature is equivalent to the forming start temperature because of no forming. The higher the temperature just before die quenching, the larger the effect of quenching becomes. The $22 \mathrm{MnB} 5$ and $440 \mathrm{MPa}$ sheets are quenched above 650 and $700{ }^{\circ} \mathrm{C}$, respectively, and the tensile strength is greatly changed around the phase transformation.

Table 2 Levels of tensile strength and total elongation of die-quenched steel sheets without and with phase transformation during natural air cooling

\begin{tabular}{|c|c|c|c|c|c|}
\hline & $\begin{array}{l}\text { Transformation during } \\
\text { natural air cooling }\end{array}$ & Non-quenchable & $270 \mathrm{MPa}$ & $440 \mathrm{MPa}$ & $22 \mathrm{MnB} 5$ \\
\hline \multirow[t]{2}{*}{ Level of tensile strength } & Without & Low, $600 \mathrm{MPa}$ & Low, $500 \mathrm{MPa}$ & Middle, $1100 \mathrm{MPa}$ & High, $1500 \mathrm{MPa}$ \\
\hline & With & Low, $400 \mathrm{MPa}$ & Low, $300 \mathrm{MPa}$ & Low, $500 \mathrm{MPa}$ & Low, $700 \mathrm{MPa}$ \\
\hline \multirow[t]{2}{*}{ Level of total elongation } & Without & High, $20 \%$ & High, $20 \%$ & Low, $5 \%$ & Low, $5 \%$ \\
\hline & With & High, $25 \%$ & High, $30 \%$ & High, $25 \%$ & Middle, $15 \%$ \\
\hline
\end{tabular}


Fig. 6 Procedure of hot stamping experiment of tailor-welded blanks into hat shape

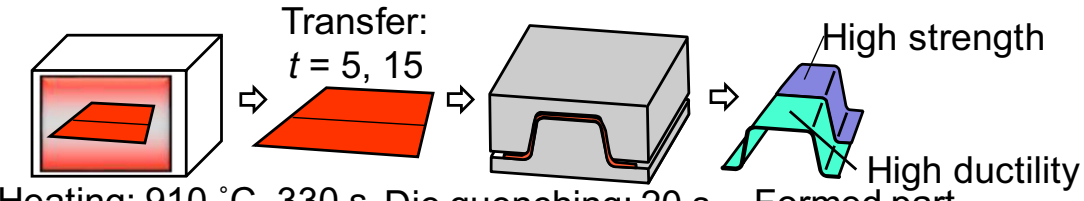

Heating: $910{ }^{\circ} \mathrm{C}, 330 \mathrm{~s}$ Die quenching: $20 \mathrm{~s}$ Formed part

(a) Hot stamping of tailor-welded blank

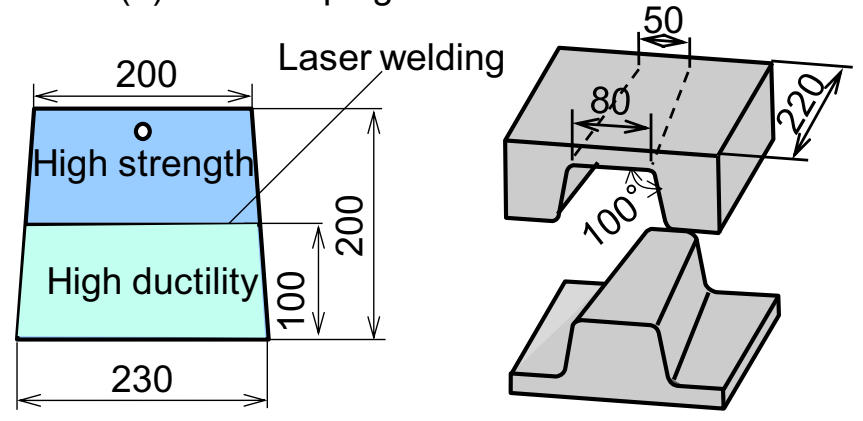

(c) Dies
The strengths for the $270 \mathrm{MPa}$ and non-quenchable sheets are almost constant, and the strength for the quenched $270 \mathrm{MPa}$ sheet is lower than that for the quenched non-quenchable sheet.

The relationship between the total elongation and the temperature just before die quenching for the 4 sheets was given in Fig. 4. Although the elongations for the $270 \mathrm{MPa}$ and nonquenchable sheets are large even at high temperatures just before die quenching, that at $850{ }^{\circ} \mathrm{C}$ for the non-quenchable sheet drops and the tensile strength shown in Fig. 3 also increases.

The microstructures of the die-quenched sheets without and with the phase transformation during natural air cooling are shown in Fig. 5. For the quenched 22MnB5 and $440 \mathrm{MPa}$ sheets, the microstructures without the transformation during natural air cooling are martensite, and those with the transformation are pearlite and ferrite, respectively. On the other hand, the microstructures without and with the transformation during natural air cooling for the $270 \mathrm{MPa}$ and non-quenchable sheets are ferrite, whereas those without the transformation during natural air cooling are finer.

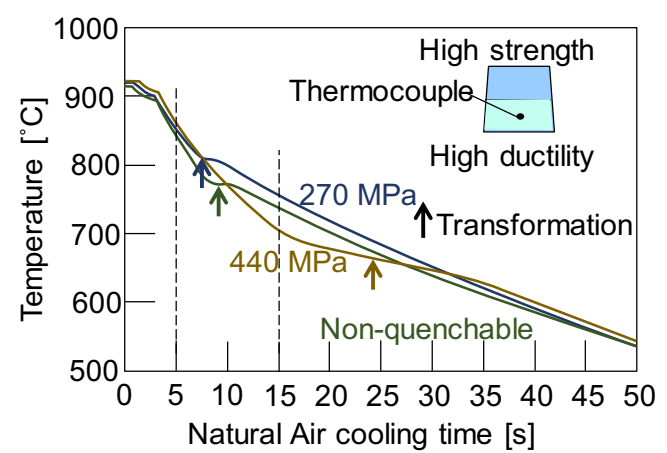

Fig. 7 Variation in temperature and phase transformation of partner sheets of tailor-welded blanks in natural air cooling
The levels of the tensile strength and total elongation of the die-quenched steel sheets with and without the phase transformation during natural air cooling are summarised in Table 2. The $270 \mathrm{MPa}$ and non-quenchable sheets are available as partner sheets having high ductility, whereas the $440 \mathrm{MPa}$ sheet is insufficient as a partner sheet.

\section{Hot stamping of tailored parts having high strength and ductility zones using tailor-welded blanks}

\subsection{Procedure of hot stamping}

The 22MnB5 sheet was laser-welded with the non-quenchable, $270 \mathrm{MPa}$ and $440 \mathrm{MPa}$ sheets as partner sheets, and the three tailor-welded blanks were hot-stamped into a hat shape. The $22 \mathrm{MnB} 5$ sheet was formed into a high strength zone, and the rest of the three sheets were formed into a high ductility zone. The procedure of a hot stamping experiment of

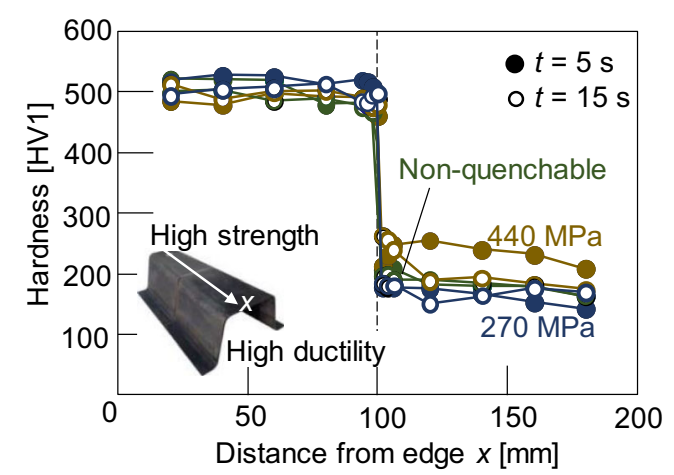

Fig. 8 Distributions of Vickers hardness in hat-shaped parts for $t=5$ and $15 \mathrm{~s}$ 


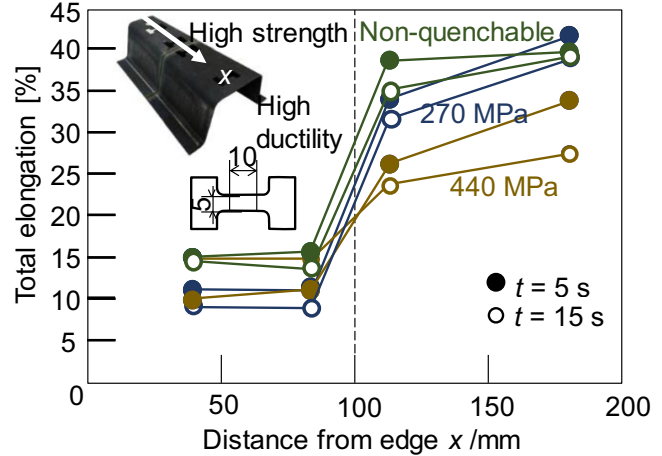

Fig. 9 Distributions of total elongation in hat-shaped parts for $t=5$ and $15 \mathrm{~s}$

the tailor-welded blanks is illustrated in Fig. 6. The blank was heated to $910{ }^{\circ} \mathrm{C}$ for $330 \mathrm{~s}$ in the electric furnace, and the transfer time from the furnace to the dies were $t=5$ and 15 $\mathrm{s}$, because the common transfer time in practical hot stamping operations is between 5 and $15 \mathrm{~s}$. The heated blanks were bend into a hat shape, and then was fully die-quenched by a holding time of $20 \mathrm{~s}$ at the bottom dead centre of a press. No cracking occurred around the welds of all the formed parts.

The variation in temperature and the phase transformation of the partner sheets of the tailor-welded blanks in natural air cooling are shown in Fig. 7. For $t=5 \mathrm{~s}$, all the partner sheets

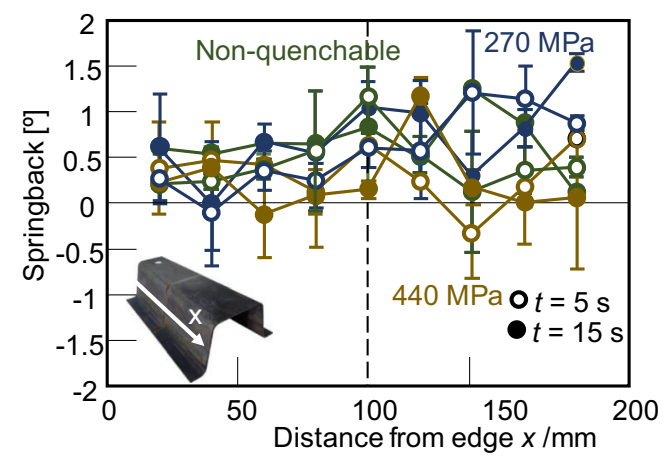

Fig. 11 Distributions of springback of sidewall of hat-shaped parts

are die-quenched before the phase transformation, whereas the $270 \mathrm{MPa}$ and non-quenchable sheets are die-quenched after the transformation for $t=15 \mathrm{~s}$.

\subsection{Results of hot stamping}

The distributions of the Vickers hardness in the hat-shaped parts for $t=5$ and $15 \mathrm{~s}$ are illustrated in Fig. 8. The hardness in the high strength zone is about $500 \mathrm{HV} 1$, and those in the high ductility are below $200 \mathrm{HV} 1$ except for $t=5 \mathrm{~s}$ of the 440 MPa sheet.
Fig. 10 Microstructures of hatshaped parts for $t=5$ and $15 \mathrm{~s}$

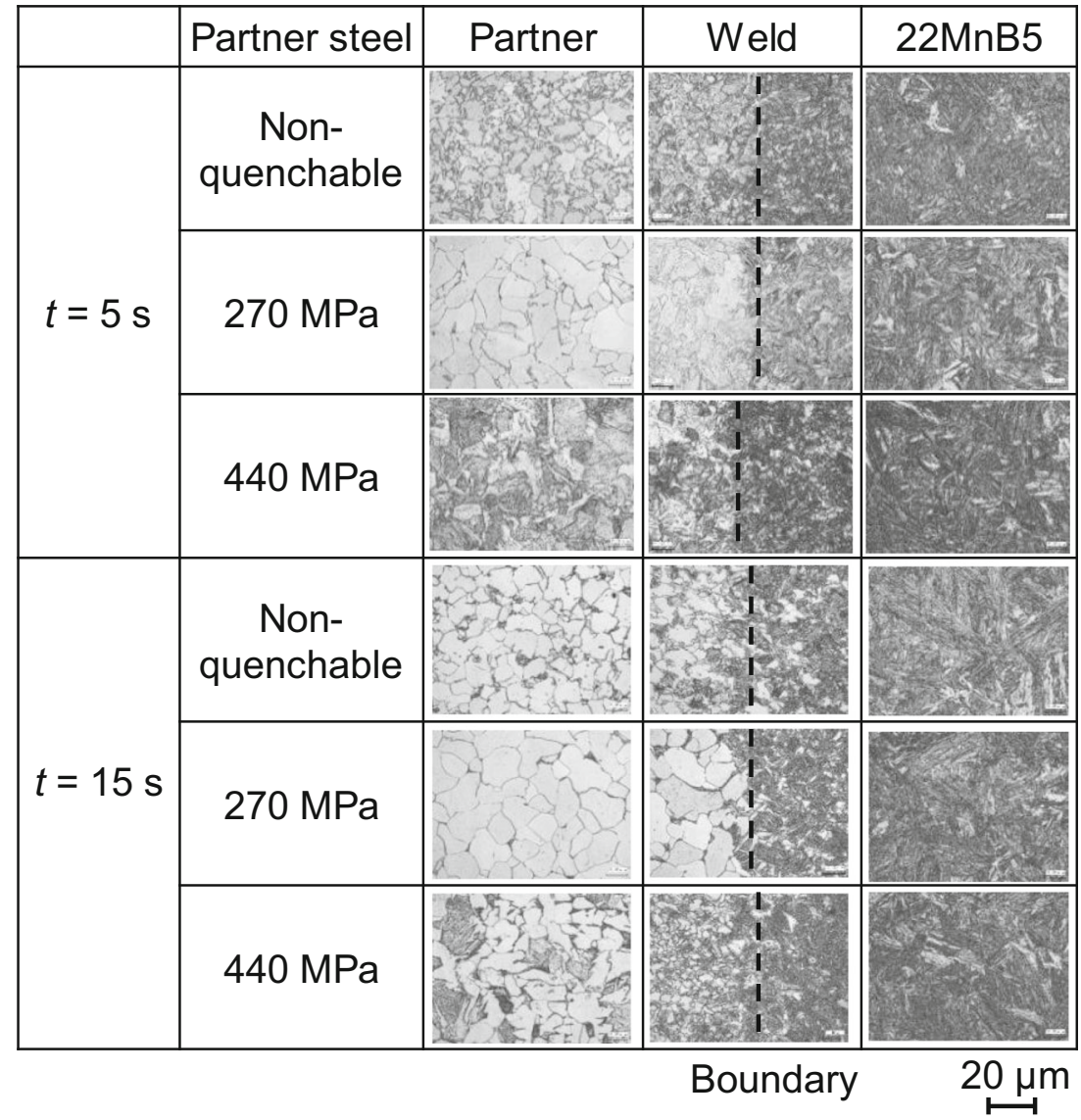



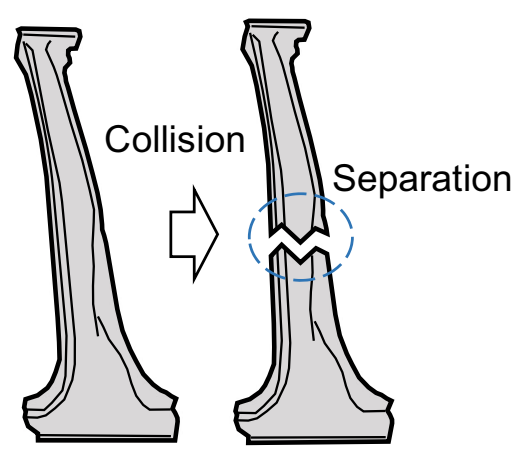

(a) Without patch

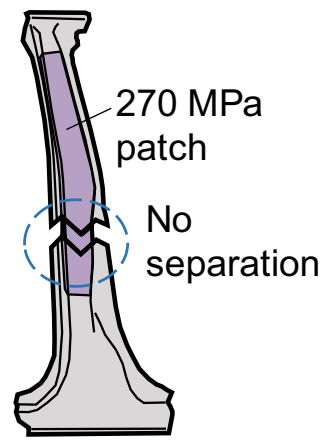

(b) With patch

Fig. 12 Prevention of separation of hot-stamped components using 270 $\mathrm{MPa}$ patch having high ductility for safety improvement

The distributions of the total elongation in the hatshaped parts for $t=5$ and $15 \mathrm{~s}$ are shown in Fig. 9, where small tensile specimens were cut from the hatshaped parts by wire electrical-discharge machining. Due to the small specimen, the elongation shown in Fig. 9 is larger than that in Fig. 4. The elongations for the $270 \mathrm{MPa}$ and non-quenchable sheets are large, and that for the $440 \mathrm{MPa}$ is lower. It was found that the 270 MPa sheet has similar ductility and strength to the nonquenchable sheet.

The microstructures of the hat-shaped parts for $t=5$ and $15 \mathrm{~s}$ are given in Fig. 10. All the high strength zones composed of the $22 \mathrm{MnB} 5$ sheet are transformed into martensite. The microstructures of the $270 \mathrm{MPa}$ sheet for $t=5$ and $15 \mathrm{~s}$ are ferrite, and the microstructure for $t=5 \mathrm{~s}$ of the non-quenchable sheet is finer. The microstructure of the $440 \mathrm{MPa}$ sheets for $t=5 \mathrm{~s}$ is martensite, and thus, the $440 \mathrm{MPa}$ sheet is not suitable for a short transfer time to dies.

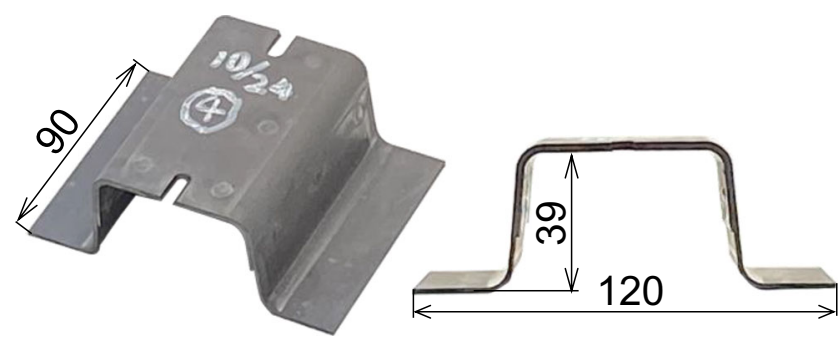

Fig. 14 Hot-stamped patchwork blank composed of 22MnB5 main blank and $270 \mathrm{MPa}$ patch

The distributions of the springback of the sidewall of the hat-shaped parts are shown in Fig. 11. Although the springback of all the three tailored blanks is relatively small, the springback of the high ductility zone tends to be larger than that of the high strength zone. This is due to no martensite transformation at low temperatures [2].

\section{Application of $270 \mathrm{MPa}$ mild steel sheet to improvement of safety of hot-stamped components}

\subsection{Prevention of separation of fractured components using $270 \mathrm{MPa}$ patch}

As another application, an approach for improving the safety of hot-stamped components using the $270 \mathrm{MPa}$ sheet having high ductility after die quenching is proposed. Although hot-stamped components having high strength hardly deform, the components are fractured by a small displacement because of low ductility. When the component is fractured by a collision of automobiles,
Fig. 13 Procedure of hot stamping experiment of patchwork blank composed of 22MnB5 main blank and 270 MPa patch

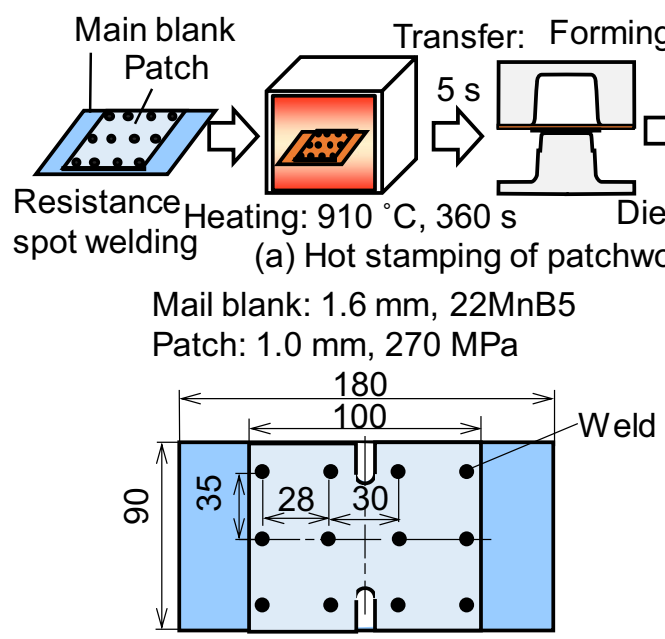

(b) Patchwork blank

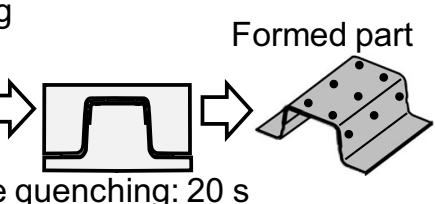

Die quenching: $20 \mathrm{~s}$

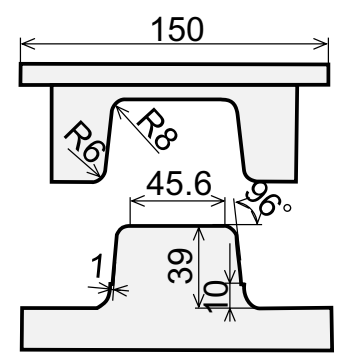

(c) Dies 


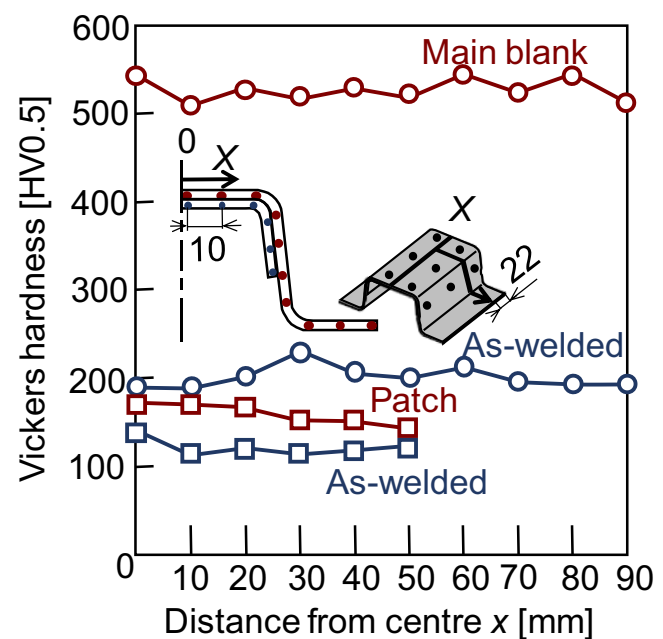

Fig. 15 Distributions of Vickers hardness of main blank and patch before and after hot stamping

separated pieces fly at a high speed due to rapid release of collision energy, and this is very dangerous [28]. This separation is prevented by welding with a $270 \mathrm{MPa}$ mild steel patch having high ductility even after hot stamping. A patchwork blank is produced by welding a $22 \mathrm{MnB} 5$ main blank with the $270 \mathrm{MPa}$ patch, and the patchwork blank is hot-stamped. Even if the hot-stamped main blank is fractured by the collision, the fractured pieces are not separated by the $270 \mathrm{MPa}$ patch having high ductility, as shown in Fig. 12.

The hot stamping process of the patchwork blank is illustrated in Fig. 13. A 22MnB5 main blank and $270 \mathrm{MPa}$ patch were resistance-spot-welded, the patchwork blank was heated to $910{ }^{\circ} \mathrm{C}$ for $360 \mathrm{~s}$ in the electric furnace, and then was hotstamped into a hat shape. The thicknesses of the main blank and patch were 1.6 and $1.0 \mathrm{~mm}$, respectively. As a

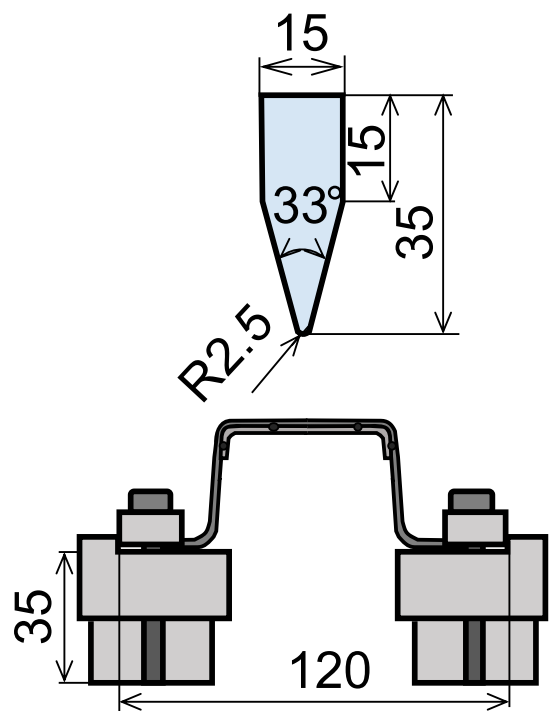

Fig. 16 Collapse test of hot-stamped patchwork blank

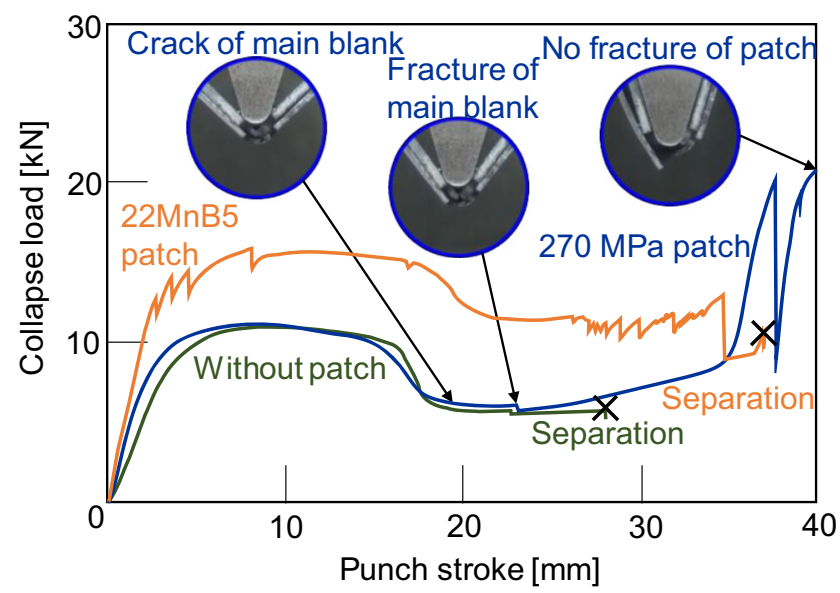

Fig. 17 Collapse load-punch stroke curve for hot-stamped patchwork blank

comparison, a patchwork blank with a 22MnB5 patch was hot-stamped. Since the patch is only to prevent the separation, a thinner and smaller patch is used because of less increase in weight.

\subsection{Results of hot stamping}

The hot-stamped patchwork blank composed of the 22MnB5 main blank and $270 \mathrm{MPa}$ patch is given in Fig. 14. The springback of the formed blank is small.

The distributions of Vickers hardness in the main blank and patch before and after hot stamping are shown in Fig. 15. Although the 22MnB5 main blank is sufficiently diequenched, the $270 \mathrm{MPa}$ patch is not hardened.

\subsection{Results of collapse test}

The collapse test of the hot-stamped patchwork blank is illustrated in Fig. 16. The centre of the top of the formed blank is pushed with the sharp punch under fixing both flanges. The punch speed was $10 \mathrm{~mm} / \mathrm{min}$, and the test was finished when the main blank separated or the punch stroke attained $40 \mathrm{~mm}$.

The collapse load-punch stroke curve for the hot-stamped patchwork blank is illustrated in Fig. 17. The collapse load fluctuates for cracking of the welds. The blank without a patch and the patchwork blank with the 22MnB5 patch separate at punch strokes of 28 and $37 \mathrm{~mm}$, respectively, and the 270 MPa patch does not fracture up to a stroke of $40 \mathrm{~mm}$ even for the fracture of the main blank. The loads for the hotstamped patchwork blank with the $270 \mathrm{MPa}$ patch and without a patch are similar because of the thin and soft patch.

The hot-stamped parts after the collapse test are shown in Fig. 18. Although the hot-stamped blank without a patch and the hot-stamped patchwork blank with the 22MnB5 patch separate, the hot-stamped patchwork blank with the $270 \mathrm{MPa}$ patch does not separate. Even if the 
Fig. 18 Hot-stamped parts after the collapse test

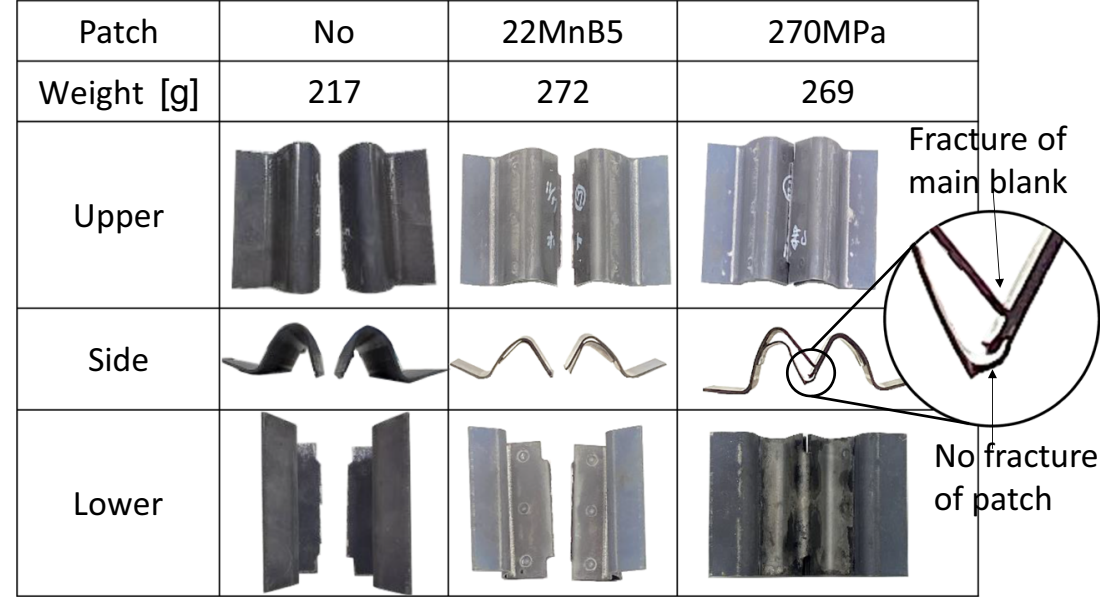

main blank fractures, the $270 \mathrm{MPa}$ patch does not fracture. It was found the $270 \mathrm{MPa}$ patch is useful to prevent the separation of fractured components. Although the large patch was employed in this experiment, it is sufficient that portions having a comparatively high risk of fracture are locally patched.

\section{Conclusions}

Hot stamping of tailor-welded blanks is increasingly applied to production of automobile tailored components to heighten the flexibility in design. In hot stamping of tailored components having partially high strength and ductility from tailor-welded blanks, the phase transformation and mechanical properties of three partner steel sheets for the quenchable $22 \mathrm{MnB} 5$ steel sheets were examined. The partner steel sheets were a non-quenchable steel, $270 \mathrm{MPa}$ mild steel, and $440 \mathrm{MPa}$ high strength steel. In addition, an approach for improving the safety of hot-stamped components using the $270 \mathrm{MPa}$ sheet having high ductility after die quenching was proposed. The obtained results are summarised as follows:

(1) The early transformation during the transfer to dies for the non-quenchable and $270 \mathrm{MPa}$ mild steel sheets was appropriate for transforming the $22 \mathrm{MnB} 5$ steel sheet into martensite.

(2) The $270 \mathrm{MPa}$ sheet was available as a partner sheet having high ductility after die quenching as well as the nonquenchable sheet, whereas the $440 \mathrm{MPa}$ sheet is insufficient.

(3) Tailored components having a hardness of about 500 HV1 in the high strength zone and a total elongation of about $30 \%$ in the high ductility zone were successfully hot-stamped from a tailor-welded blank composed of $22 \mathrm{MnB} 5$ and $270 \mathrm{MPa}$ sheets.
(4) The safety of hot-stamped components was improved by preventing the separation of fractured components using a 270 MPa steel patch.

The 270 MPa mild steel sheet keeps a ferrite structure after die quenching and has similar high ductility to the non-quench steel sheet. The $22 \mathrm{MnB} 5$ sheet is superior as a quenchable steel sheet due to late ferrite transformation. The use of the low-cost conventional mild steel sheet for a partner sheet in hot stamping of tailor-welded blanks is effective.

Although the hot-stamped components have high strength, fractured components are very dangerous due to flying of separated pieces. The separation is prevented by welding a $22 \mathrm{MnB} 5$ main blank with a $270 \mathrm{MPa}$ patch. Even if the main blank fractures, the patchwork component is not separated by the $270 \mathrm{MPa}$ patch having high ductility. The increase in weight of the patchwork blank is not very large, because the $270 \mathrm{MPa}$ patch is thin and partial. It is effective that portions having a comparatively high risk of fracture are welded with the $270 \mathrm{MPa}$ patches. The safety of hot-stamped components is increasingly heightened by the $270 \mathrm{MPa}$ patch.

Funding This work was supported by JSPS KAKENHI Grant-in-Aid for Scientific Research (B) of Number JP18H01749.

Data availability The data that support the findings of this study are available from the corresponding author on reasonable request.

\section{Compliance with ethical standards}

Competing interest The authors declare that they have no competing interest.

Open Access This article is licensed under a Creative Commons Attribution 4.0 International License, which permits use, sharing, adaptation, distribution and reproduction in any medium or format, as long as you give appropriate credit to the original author(s) and the source, provide a link to the Creative Commons licence, and indicate if changes were made. The images or other third party material in this article are included in the article's Creative Commons licence, unless indicated otherwise in a credit line to the material. If material is not included in the article's 
Creative Commons licence and your intended use is not permitted by statutory regulation or exceeds the permitted use, you will need to obtain permission directly from the copyright holder. To view a copy of this licence, visit http://creativecommons.org/licenses/by/4.0/.

\section{References}

1. Billur E (2018) Chapter 1 Introduction. In: Billur E (ed) Hot stamping of ultra high-strength steels: From a technological and business perspective. Springer Nature, Cham, pp 1-18

2. Nakagawa Y, Mori K, Maeno T (2018) Springback-free mechanism in hot stamping of ultra-high-strength steel parts and deformation behaviour and quenchability for thin sheet. Int J Adv Manuf Technol 95(1-4):459-467. https://doi.org/10.1007/s00170-0171203-3

3. Mori K, Abe Y, Sedoguchi K (2019) Delayed fracture in cold blanking of ultra-high strength steel sheets. CIRP Ann Manuf Technol 68(1):297-300. https://doi.org/10.1016/j.cirp.2019.04.111

4. Berglund D, Amundsson K, Hellgren LO (2008) Hot stamped components with "soft zones" for improved crashworthiness-simulation and validation of product performance. Int Deep Drawing Research Group Proc, Sweden, C/63/08

5. Merklein M, Wieland M, Lechner M, Bruschi S, Ghiotti A (2016) Hot stamping of boron steel sheets with tailored properties: a review. J Mater Process Technol 228:11-24. https://doi.org/10.1016/ j.jmatprotec.2015.09.023

6. Mori K, Bariani PF, Behrens BA, Brosius A, Bruschi S, Maeno T, Merklein M, Yanagimoto J (2017) Hot stamping of ultra-high strength steel parts. CIRP Ann Manuf Technol 66(2):755-777. https://doi.org/10.1016/j.cirp.2017.05.007

7. Wilsius J, Tavernier B, Abou-Khalil D (2011) Experimental and numerical investigation of various hot stamped B-pillar concepts based on Usibor ${ }^{\circledR} 1500$ P, Proc 3rd Int Conf Hot Sheet Metal Forming of High-Performance Steel - CHS2, Kassel, Germany, p. $427-435$

8. Landgrebe D, Putz M, Schieck F, Sterzing A, Rennau A (2015) Towards efficient, interconnected and flexible value chainsexamples and innovations from research on production technologies. Proc 5th Int Conf Accuracy in Forming Technology, Chemnitz, p. 61-78

9. Mori K, Maeno T, Mongkolkaji K (2013) Tailored die quenching of steel parts having strength distribution using bypass resistance heating in hot stamping. J Mater Process Technol 213(3):508-514. https://doi.org/10.1016/j.jmatprotec.2012.10.005

10. Maikranz-Valentin M, Weidig U, Schoof U, Becker HH, Steinhoff K (2008) Components with optimised properties due to advanced thermo-mechanical process strategies in hot sheet metal forming. Steel Res Int 79(2):92-97. https://doi.org/10.1002/srin.200806322

11. Fernandez B, Zarate J, Garcia I, Varela S (2011) Tailored strategies in press hardening. Proc 3rd Int Conf Hot Sheet Metal Forming of High-Performance Steel - CHS $^{2}$, Germany, pp. 437-446

12. Tang BT, Wang BT, Bruschi S, Ghiotti A, Bariani PF (2014) Influence of temperature and deformation on phase transformation and Vickers hardness in tailored tempering process: numerical and experimental verifications. ASME J Manuf Sci Eng 136(5): 051018. https://doi.org/10.1115/1.4027816

13. Bardelcik A, Vowles CJ, Worswick M (2018) A mechanical, microstructural, and damage study of various tailor hot stamped material conditions consisting of martensite, bainite, ferrite, and pearlite. Metall Mater Trans A 49(1):1102-1120. https://doi.org/10. 1007/s11661-018-4471-0
14. Omer K, Kortenaar L, Butcher C, Worswick M, Malcolm S, Detwiler D (2017) Testing of a hot stamped axial crush member with tailored properties - experiments and models. Int J Imp Eng 103:12-28. https://doi.org/10.1016/j.ijimpeng.2017.01.003

15. Nakagawa Y, Mori KI, Suzuki Y, Shimizu Y (2020) Tailored tempering without die heating in hot stamping of ultra-high strength steel parts. Mater Des 192:108704. https://doi.org/10.1016/j. matdes.2020.108704

16. Merklein M, Johannes M, Lechner M, Kuppert A (2014) A review on tailored blanks-production, applications and evaluation. J Mater Process Technol 214(2):151-164. https://doi.org/10.1016/j. jmatprotec.2013.08.015

17. Min KB, Kim KS, Kang SS (2000) A study on resistance welding in steel sheets using a tailor-welded blank (1st report) evaluation of upset weldability and formability. J Mater Process Technol 101(13):186-192. https://doi.org/10.1016/S0924-0136(00)00476-3

18. Kinsey B, Liu Z, Cao J (2000) A novel forming technology for tailor-welded blanks. J Mater Process Technol 99(1-3):145-153

19. Chan SM, Chan LC, Lee TC (2003) Tailor-welded blanks of different thickness ratios effects on forming limit diagrams. J Mater Process Technol 132(1-3):95-101. https://doi.org/10.1016/S09240136(02)00407-7

20. Padmanabhan R, Oliveira MC, Menezes LF (2008) Deep drawing of aluminium-steel tailor-welded blanks. Mater Des 29(1):154 160. https://doi.org/10.1016/j.matdes.2006.11.007

21. Choi JW, Lee MG, Barlat F, Son HS, Nam JB (2012) Hot press forming of tailor welded blank: experiments and FE modeling. ISIJ Int 52(11):2059-2068. https://doi.org/10.2355/isijinternational.52. 2059

22. Choi JW, Bok HH, Barlat F, Son HS, Kim DJ, Lee MG (2013) Experimental and numerical analyses of hot stamped parts with tailored properties. ISIJ Int. 53(6):1047-1056. https://doi.org/10. 2355/isijinternational.53.1047

23. Kang M, Kim YM, Kim C (2016) Effect of heating parameters on laser welded tailored blanks of hot press forming steel. J Mater Process Technol 228:137-144. https://doi.org/10.1016/j. jmatprotec.2015.06.028

24. Tang B, Wang Q, Wei Z, Meng X, Yuan Z (2016) FE simulation models for hot stamping an automobile component with tailorwelded high-strength steels. J Mater Eng Perform 25:1709-1721. https://doi.org/10.1007/s11665-016-2011-X

25. Tang B, Yuan Z, Cheng G, Huang L, Zheng W, Xie H (2013) Experimental verification of tailor welded joining partners for hot stamping and analytical modeling of TWBs rheological constitutive in austenitic state. Mater Sci Eng A 585:304-318. https://doi.org/ 10.1016/j.msea.2013.07.059

26. Kong H, Chao Q, Rolfe B, Beladi H (2019) One-step quenching and partitioning treatment of a tailor welded blank of boron and TRIP steels for automotive applications. Mater Des 174:107799. https://doi.org/10.1016/j.matdes.2019.107799

27. Múnera DD, Pic A, Abou-Khalil D, Shmit F, Pinard F (2009) Innovative press hardened steel based laser welded blanks solutions for weight savings and crash safety improvements. SAE Int J Mater Manf 1(1):472-479. https://doi.org/10.4271/2008-01-1076

28. Abe Y, Okamoto Y, Mori K, Jaafar H (2017) Deformation behaviour and reduction in flying speed of scrap in trimming of ultra-high strength steel sheets. J Mater Process Technol 250:372-378. https:// doi.org/10.1016/j.jmatprotec.2017.07.034

Publisher's note Springer Nature remains neutral with regard to jurisdictional claims in published maps and institutional affiliations. 